\title{
Microfilm in University Libraries: A Report*
}

In 1950-5I, the ALA Serials Committee selected as one of its projects "the evaluation of the acceptance of microfilm by the clientele of public, college, university and research libraries." To conduct the survey a subcommittee of three was appointed, and as each of the members had two-year tenure on the Committee, the work was to be accomplished in that period of time.

By a later decision, the survey was limited to just college and university libraries but the scope was broadened to include other pertinent information on microfilm in university libraries. Data gathered covered such topics as the extent and type of the microfilm holdings, the reading machines, the physical facilities, the use of the film, patron reaction to microfilm, purchasing policies, current subscriptions on microfilm, binding vs. microfilms for storage, and the effect of clientele opinion of film as a factor in its acquisition. Consideration was given also to including other forms of microreproduction but the vote was to limit the survey just to microfilm.

The ninety-four institutions chosen for the survey include most of the large graduate schools, the libraries with good financial support, and those with high enrollments. Rapidly growing young colleges as Wayne, Houston, the University of Miami, and Brooklyn College, but whose libraries are comparatively small, were also included. Although all types of colleges were chosen and from all sections of the nation, the three main factors for inclusion were nature of graduate program, enrolment which generally exceeded 5000 students, and geographical distribution. We wished to have data from not less than 70 libraries.

As nine librarians did not reply to our questionnaire, two others failed to furnish the

* This report was submitted June I7, I952, to the Harkins is chairman of the Subcommittee. data as promised, three submitted negative reports because of meager holdings and equipment, one sent a return too incomplete for use, and one was unwilling to cooperate, the data for the survey have come from 76 college or university libraries.

The combined microfilm holdings of reporting libraries totaled 164,57 I reels. Participating libraries were requested to equate the number of reels to Ioo feet, and generally the figure reported represented reels of that length. Of the six categories or types of materials on film, by far the greatest number of reels was of newspapers, the combined holdings being 98,612 . The other materials in order were 16,934 reels of books, 10,066 of manuscripts, 10,053 of periodicals, 6,977 of documents with more than one third of the total reported by one library, I,762 of separates, and $2 \mathrm{I}, 047$ reels undivided by type of material.

Because the number of reels of microfilm in the libraries reporting vary from 3 to 20,000 , no median has been established, but in Table I is a broad breakdown of the microfilm resources according to number of reels for the various types of publications in libraries. Dividing the libraries into two groups, those with 1000 or more reels and those with less than I000, we find the former to be 43 as against 33 for the latter; however, further division by thousands shows 20 libraries with 1000-1999 reels, 5 with 20002999, 7 in the 300o's, 6 in the 400o's, I each in the 5000's and 6000's, and 2 with 10,000 or more. Thus, the number of reels common to the highest number of libraries is less than Iooo.

Table II lists by type of resource the 43 college and university libraries whose microfilm holdings number 1000 or more reels. There is, of course, no magic in the number I000, but it is a good point of departure.

Libraries reporting holdings of fewer than 
Iooo reels were Alabama Polytechnic, Arizona, Boston University, Brooklyn College, Cincinnati, Cornell, Connecticut, Dartmouth, Denver, Fordham, Georgia Tech., Georgia, Houston, Idaho, Iowa State, Joint University, Kansas State, Maryland, University of Miami, Michigan State, Mississippi State, Mississippi, Montana State, City College of New York, Oregon State, Oregon, Pennsylvania State, Rice, St. Louis University, Southern Methodist, Syracuse, Texas A \& M, Virginia Polytechnic, Western Reserve, and Wyoming. The following institutions either furnished no report or failed to list holdings where a return was made: Baylor, Louisville, Massachusetts Institute of Technology, Nebraska, New York University, North Carolina State, Northwestern, Oklahoma A \& M, Oklahoma, Purdue, Tulane, Washington State, and West Virginia.

Analyzing the reports from seventy libraries on their reels of newspapers, it is seen that the greatest number, 46 , have fewer than I 000 reels, 2 I have from I000-4999, and only 3 have more than 5000 . Of the 46 reporting below 1000 reels, the highest concentration is less than 600 reels, the division being 8 in the 400's, 7 with fewer than I00, 6 having 200299 reels, 5 each in the 500's and I0o's, and 4 libraries having from 300 to 399 reels, or a total of 39 .

Libraries with a rather high number of newspapers on film but not listed by name because the total holdings fell below 1000 reels are the following: Arizona 60o, Brooklyn 772, Cornell 330, Dartmouth 266, Fordham 29I, Georgia Tech. 448, Georgia 443, Iowa State 562, Miami 408, Mississippi State 230, City College of New York 223, Oregon State 816, Oregon 429, Pennsylvania State 516, Southern Methodist 300, Virginia Polytechnic 200, Western Reserve 447, and Wyoming 589 .

The concentration of periodicals on film is below 250 reels, 42 of 54 libraries which reported indicating holdings in that number. Tabulated in IOo's, the division is 22 libraries with fewer than 100 reels, II with from 100 to 199, the same number for 200's, 3 in the 300 's, 4 in the 400's, 2 in the 500's and I library with more than 500 , the count for it being I200. Institutions omitted from the table above but whose microfilm periodicals holdings number 100 reels or more are: Alabama Polytechnic I78, Georgia I 70, Maryland
239, Miami 239, City College of New York 2 Io, Southern Methodist Ioo, Western Reserve I99, and Wyoming I40.

For books, manuscripts, documents, and separates, the concentration of holdings in each is fewer than Ioo reels.

Books numbering Ioo or more reels in libraries not listed above are: Cornell 270, Michigan State 574, and Rice 402. Of manuscripts, numbering 100 plus reels, Georgia has 139 and Rice I35; of documents, Oregon has 300 .

That periodicals equal only about $7 \%$ of the total reels of microfilm held by 64 libraries whose reports furnished data on this type of material came as a surprise to the members of the subcommittee. The comparative low number of reels of periodicals is due in part to that type of material having been available commercially just for the last few years, but the main reason seems to be due to libraries following a policy to wait and watch. How long the practice will continue, no one can tell; however, it is our belief that except for projects such as the early American and British periodicals, libraries in general will continue to be slow to increase their holdings of magazines on film in proportion to other resources. For that matter, the same is felt to be true for all types of microfilm acquisitions except newspapers. From time to time, there have appeared in the professional journals great claims for microfilm, and certainly it fills a very definite need, but until the reading machines are improved even more, the public is better educated in its use, and librarians overcome apathy, microfilm will remain largely a step-child of the various media and too of ten will be turned to only as a last resort for supplying needed references.

In answer to the question of whether the library was subscribing to periodicals on microfilm in preference to binding the printed issues, of a total of 70 replies, only 18 were in the affirmative. This figure is out of line with that furnished by Eugene $B$. Power, of the University Microfilms who reports 107 college and university libraries subscribing to current periodicals on microfilm. For newspapers on film, of 74 answers received by the subcommittee, there were 66 affirmatives.

A grouping by number* of current periodi-

* Other subscribing libraries we learned too late to include in the report are: Skidmore 80 , Vermont 80 , 
cals being received on film shows 8 libraries receive from $I$ to 9,2 have IO-I5, and 6 receive from 20 to 67 . Two libraries failed to specify the number received. The libraries subscribing to 20 or more titles are City College of New York 67, Arizona 50, Brooklyn 38, Pittsburgh 35, Iowa 32, and Southern Methodist 20. Of his I07 subscribing college libraries, $\mathrm{Mr}$. Power indicates that 52 take 20 or more titles and that one library receives 125 periodicals. No doubt, the big difference in the findings of the subcommittee and in the report from University Microfilms is that the smaller libraries are those subscribing to periodicals on film, because in the main the smaller libraries were omitted from the survey as it was not expected that they would be the principal subscribers.

Although not surprising, it is interesting to learn also from Mr. Power that of the total of 223 libraries subscribing from his company for current periodicals on film, I 16 are public libraries, and one of the number receives as many as 156 titles. The service has been operating for a very short time and the figures may only mean that college libraries were slower to act. Of further interest is his statement that

". . . the tendency is to purchase the most popular and most used periodicals, whereas, actually, intelligent application of this whole theory would indicate that the less used, but nonetheless space-consuming, foreign periodicals are the ones which should be kept on film. All of this indicates to me that librarians have not as yet carefully and thoroughly thought through the application and the implications of microfilm copies.

It is interesting to note, however, that libraries which started the program in 1950 are continuing it and in a very large majority of cases are expanding the number of titles which they keep on microfilm. In addition, new libraries a re coming in quite frequently, which indicates an increasing interest and approval of this method.

Any program of this sort must of necessity start slowly, and we are not disappointed that it has not gone faster. In fact, it has gone about the way we anticipated. However, we are convinced of the soundness and logic of the program, and that it will continue to grow."

California State Poly. 56, Wright Junior 50, Idaho State 28, Principia 25, Tarleton State 22, Howard Payne 20, Rosemont 13, George Pepperdine i 2', and New Hampshire 3.
Unfortunately, our data do not reveal the number of copies of a title or all the titles on subscription nor does University Microfilms. However, Mr. Power states that of the approximate 800 titles available, from I to 57 copies of one or more of 500 periodicals are being sent to libraries. In comparing the difference between the 1950 and 1952 lists of magazines from University Microfilms, we found that i 16 titles have been crossed off the 1952 list and that they may be discontinued "because of lack of interest." Fortyfive periodicals have been added to the 1952 list, making a total of 774 of which I 16 may be discontinued.

Generally, the reasons for selecting titles to be received on microfilm by the above libraries were limited demand as currently received, little used when older than several years, cheaper than binding, and for experimentation. Five of the six libraries receiving microfilmed periodicals although not binding the printed issues are still retaining them for one reason or another, but mainly because microfilm as a substitute for printed periodicals has not yet proven satisfactory in all respects.

Of special interest were some of the comments from a few of the librarians experimenting with periodicals on microfilm. Jerome Wilcox of the City College of New York wrote:

"We are not experimenting with any of the popular periodicals but only technical periodicals. Since this is the first year we have attempted the experiment, we are not prepared to make any final statements. So far, students and faculty have made the following comments concerning microfilm editions:

a. Student and faculty members invariably prefer book material but do not object to microfilm.

b. Eyestrain rarely reported.

c. Opinion is equally divided on reading speed-microfilm vs. codex book.

d. There is a slight amount of inconvenience to both clientele and library staff in setting up and manipulating machines, but this is far outweighed by shelf space saving.

e. Illustrations in color (particularly covers) not clearly photographed; perhaps camera technique could be improved by use of filters, different exposure times, etc.

This experiment is being run entirely by School of Technology students and faculty. 
They are introduced to the operation of the equipment and thereafter operate it themselves. Since these students are mechanically minded they can probably be entrusted with operating this type of machine better than would other types of students.

We hesitate at this time to make any broad recommendations concerning widespread adoption by libraries of microfilm substitutes for bound volumes for technical periodicals."

\section{From Pittsburgh, A. L. Robinson stated:}

"We have a very favorable reaction to the use of film as a substitute for the printed issues. No popular titles were selected. We believe that the cost of servicing the film to the public is less than it would be for bound volumes. The films are kept in the Reference Department where our film readers are also located so that we can produce the reel of film much more quickly than the bound volume which has to be brought from the Stacks which are a considerable distance away. If the client has used one of our microfilm readers before, we permit selfservice of the film. If the client is using film for the first time, a Reference Department assistant places the film on the reader and removes it after use. Even this much service we consider to be less than that involved in supplying a bound volume.

We are very satisfied with our program largely because we seem to have selected titles which are seldom called for. This was our major purpose. As I have pointed out, these films can be supplied to our readers more quickly than bound volumes. The films cost no more than binding, which we have now discontinued for these 35 titles. We will soon decide whether to discard the printed issues. I suspect that our decision will be to discard them and thus a certain amount of stack space will be saved in addition to the other advantages pointed out."

On the basis of experience at Brooklyn, Humphrey Bousfield reported:

"To date the use of the microfilm copies has been relatively small due to the fact that until very recently we had not discarded any printed issues. There are distinct disadvantages in the use of microfilm. We have only two 'readers' so only two persons can be accommodated at a time. More time and labor is employed in installing the film than in charging the bound volume. This is especially true where the reader desires only to scan several volumes. We do not permit readers to install films as this may damage either the micro-reader or the film. On the other hand, as microfilm copies never circulate, no time is lost in locating a film; nor do film copies suffer mutilation.

Probably the most serious objection we have found concerns not the use of the microfilm but the microfilming itself. .... In nearly every case where the index was published separately and issued some time after the completion of the volume, the index was not included in the microfilm. We have had extensive correspondence with the firm on this matter. Not long ago they stated they would suspend operations until they had straightened out this matter, but only last month we received another title where the index was missing. Considerable time is spent examining film for such errors. In one case a spot check revealed that the inside front cover and first page were omitted. In another case the tpi was microfilmed where the publisher had tucked it in behind the cover of the last issue, instead of photographing it at the beginning of the film. In several instances where the publisher employs dark-colored covers, the covers are completely or almost completely invisible on microfilm; the cover illustrations of Nature Magazine, for instance, are virtually invisible."

\section{Mr. Robert Trent's statement from SMU} was:

"We selected only scientific, technical and professional journals on microfilm, those which are necessary for research but which will not be frequently used by anyone and hardly ever by undergraduates.

Film is an unsatisfactory substitute for the original. It is more inconvenient to use, it is harder on the eyes, charts and diagrams on film are not too satisfactory, cost of servicing a film is greater than a bound volume. Yet, it is the only answer to the storage problem.

We would not recommend that other libraries buy much used periodicals on film unless they can also bind the originals. Many people forget, in counting the saving of film over bound volumes; that additional reading machines are necessary, that these are expensive, and that they take floor space and servicing.

We do not regret our decision so far, but we have tried to be very careful in our selection of titles. We do not do a great deal of research here now. As our research program grows, we may have problems."

At Iowa, the variety of titles selected was wider, and so the experiences have been somewhat different. Norman Kilpatrick replied: 
"On list I, you will find such titles as, the Atlantic Monthly, Foreign Affairs, Harpers, etc. We experimented with this type of material on film, thinking that after the first year these general periodicals were infrequently used and, therefore, the film copy would be sufficient. However, our experience so far has proven that this is not so and we recently decided that we would continue to bind Atlantic Monthly, Harpers, Reader's Digest and Popular Science Monthly. We are going to try out a scheme of plastic binding which we can do here rather than send the items out. We did not discontinue the film for these titles because frequently an issue is missing and the use seemed heavy enough to warrant having a film as well as the bound copy. For the other material on this list, Country Gentlemen, Library Journal, National Real Estate and Building Journal, etc. we are still withholding a final opinion.

On list II, you will note that all of the material is medical. Here we were of the opinion that the quarterlies and the reviews were used extensively when they first came, but little use was made after a few months. Two of these titles, Occupational Therapy and Rehabilitation and the Quarterly Review of Ophthalmology and Allied Sciences, have had such heavy use that we have decided that the film is no substitute and, therefore, have canceled the film subscription for these titles.

It is our opinion that for journals that have considerable use the film is not satisfactory, but that it is satisfactory for those journals that have very little use after the first few months. I am not able to define exactly what titles these would be, but in our situation we would include such items as, Quarterly $R \boldsymbol{e}$ view of Biology, Quarterly Review of Medicine, Quarterly Review of Obstetrics and Gynecology, Country Gentlemen, Library Journal, Social Forces and Survey."

Of 75 replies received to the question, "Do you contemplate changing the current magazine files from binding to film?" only $40 \%$ were unqualified. There were 26 "No's"; 7 which stated "No, with exceptions"; I "Save as needed"; I "Can not answer now, undoubtedy will come to it"; 2 "Discussed"; 8 "Considering"; I I "Not at present"; I "Would like to"; I "Few, soon"; I "Selected group in two years"; I "To experiment in one department"; "Plan in a year or so"; 6 "Experimenting"; I "Yes, but wish to retain printed copy"; and 4 "Yes's." Certainly, it is evident librarians at least are thinking on the question of microfilm as a substitute for bind- ing, but mainly because storage space has become so pressing a problem. The one most optimistic library reported that $50 \%$ of its periodicals would be on microfilm if proven satisfactory after 5 years of service.

For newspapers, the grouping by number of titles received is as follows: 44 libraries receive fewer than I 3 titles, 3 are in the 20's, 2 in the 30's, 2 in the $40^{\prime} \mathrm{s}, \mathrm{I}$ in the $50^{\prime} \mathrm{s}$, and one receives "too many to list." The other I3 libraries reporting newspapers on microfilm in preference to binding fail to list the number of titles being received. Further analysis for the libraries with fewer than 20 newspapers show I2 have I title, I3 have 2, 5 have 3,3 have 4,3 have 5,4 have 6 , I has 7 , and 3 have 13 . Almost without exception, the one newspaper received on film is the New York Times, even where it is the only title.

Do libraries have definite policies for the purchasing of microfilm? Seventy-two libraries furnished answers to the question. Forty reported negatively, thirty replied affirmatively, and two were classed as limited. The point on which there was the most agreement was that newspapers if kept on file should be on microfilm. Other factors common in the policies were meeting urgent needs for graduate and faculty research, acquiring items available in print but too costly to buy, completing gaps in perodical runs, to overcome bulk and disintegration, to save purchasing rare and expensive items, to make available little used material and especially sets of limited use, and to acquire only when available in no other form except microfilm. Points mentioned singly by the libraries as a part of their policies were the acquisition of general and literary periodicals prior to 1850 as available on microfilm, scientific magazines when too expensive or unavailable otherwise were to be bought on film, to purchase microfilm of some principal source materials and early runs of research periodicals where use is limited, to acquire long runs of foreign periodicals, to save wear and tear on originals, and to meet interlibrary loan needs. Only two libraries mentioned a time factor in their policies, one stated, "MonographsRefer items searched for one year to source of request for decision on purchase of film. Serials-Missing issues-Order is submitted with note as to whether microfilm is acceptable after trying two dealers for originals." The 
other reported, "Books: If we cannot obtain original, and at a satisfactory price, we purchase on microfilm after a 'search' period of 6 months." Another comment of interest on a purchasing policy was the statement from one library that its policy was one of expediences and that it was "reluctantly backing into using microfilm."

Of governing factors in purchasing microfilm, the one reported most important was the saving in storage cost or in space, fifty libraries listing it. Other points given, in order of number, were the saving in purchase cost 45 , the use to which the material was to be put 13 , the availability of a needed item II, preservation of the material 4 , the binding cost 3 , satisfying of the faculty 2 , condition of the paper 2, the time in which an item had to be furnished 2, and one each for subject content of the desired item, format of the publication, importance of the material, and service economy.

On the question of whether a film would be purchased only when the codex book was unavailable, there was a more nearly equal distribution of answers than on any other. Thirty-three libraries reported negatively and thirty-one replied affirmatively. Quite a number answering "yes" made the qualification of "generally." So strong is the aversion to film by a few libraries that where a printed book can not be bought it will not be supplied if available only on film. In quite a number of instances, the decision as to purchasing film, if available only in that form, was reported to be made by the user of the material.

As a matter of fact, in answer to the question, " $\mathrm{Has}$ the reaction, whether adverse or favorable, in using film been a major consideration in your microfilm acquisition program?" the libraries reporting "Yes" numbered 12 and those replying negatively totaled 54. Several librarians stated that the program had been slowed considerably by the resistance to film, a couple of others reported buying film only with the approval of the academic departments, and there was one specific instance where acquiring the New York Times on film was delayed two years because of adverse opinion. However, other libraries reported favorable reception of film had acted as a stimulant to the buying program and one institution sometimes splits the cost of the film between the library and an academic department. There was only one report that newspapers on microfilm had been purchased because of faculty insistence.

Of 75 libraries reporting on their microfilm facilities, only three claimed them to be excellent. Forty-six others replied that they were adequate and 26 reported them to be inadequate. No definition was given in the questionnaire for the meaning of "adequate," and so the standards set are those of the individual libraries. Some did state, however, that the facilities were adequate for present needs. In comparing the microfilm holdings, the number of reading machines, the locations of the machines, etc. for the seventy plus libraries, there was the feeling that many of the libraries reported as adequate were really sub-standard in their microfilm facilities. Of course, the quality of the microfilm accommodations are really only the concern of the individual library; however, the subcommittee does believe that the better the facilities, the more chance there is to educate the clientele to satisfied use of microfilm, and thereby, the greater the opportunity to broaden the resources of the library.

The number of reading machines reported for 75 libraries was 307 , which would be an average of four to an institution. Actually, a grouping by number shows the following: 13 libraries to have I machine, 13 with 2 , I8 with 3,12 with 4 , I with 5,6 with 6,2 with 7,3 with 8 , I with 9, 3 with ro, and one each with 12,15 and $2 \mathrm{I}$. Libraries having four or more readers are California 2I; Chicago 15 ; Virginia I2; Columbia, Illinois, and Michigan Univ. Io; Wisconsin 9; Duke, North Carolina Univ., and Ohio State 8; Harvard and Kentucky 7; Brown, California at Los Angeles, Johns Hopkins, Missouri, Pennsylvania State and Princeton 6; Wayne 5; Arizona, CCNY, Emory, Georgia Tech, Iowa Univ., Minnesota, Rochester, Southern California, Stanford, Utah, Washington (Seattle), and Yale 4.

No doubt, quite a number of local factors determine how many reading machines are necessary to provide good service to a microfilm collection. To be sure, there is some degree of correlation between the number of reels and of the machines but it is not high. For example there are eight libraries with more than 2,000 reels of film but with four or less machines and yet six libraries with fewer than 2,00o reels have five or more readers. As to be expected, the amount of 
graduate study is a determining factor in the number of readers, but this can not be claimed as the most important factor. To arrive at any definite conclusion, much more will have to be known of individual libraries than we know now.

By far the favorite make of reader among the libraries reporting is the Recordak, 167 of one model or another out of a total of 307 machines being in use. Second highest is the Spencer with 48 , third is the Argus with 33, and fourth is the Griscombe with 32. No other make of machine was reported in more than nine libraries, although ten additional trade names were listed. Of the thirty portable readers available, several libraries stated they are loaned for as much as two weeks and one library has a loan privilege of three weeks. To make microfilm more convenient in its use, the day will have to come when many libraries have portable readers to be issued on loan.

In the location of the reading machines for servicing, it was expected that most libraries would list them as being in the reference room or department, and such was the case, fourteen being so reported. Other favorite locations were the stacks, periodical room or department, special collections room, circulation department, librarian's office, and rare book room. Machines have also been placed in the interlibrary loan office, graduate reading room, map room, newspaper room, audiovisual department, science room, archives section, music room, acquisitions department, modern language room, mathematics office, graduate history room, and English seminar. Reading machines also were reported as having been placed in the departmental libraries, the practice being to shift the older models to the branches. Thirty-two libraries indicated the reading machines are in a separate room but only three noted a microfilm reading room or department. Fifty-five of 72 libraries have their machines in locations which are dark or which may be darkened.

What proportion of the users of microfilm are undergraduates, graduate students, faculty members, and others? The percentage average for the 63 libraries replying to this question was $22.08,43.27,30.95$, and 3.74 respectively. As one might imagine, however, the group of users varied greatly from library to library. For undergraduates, I 3 libraries indicated no use, 33 reported $25 \%$ and less of total use, 8 from $26 \%$ to $50 \%$ of the users, 4 from $51 \%$ to $75 \%$, and 5 with $76 \%$ or more. The highest percentage of undergraduate use in a library was $92 \%$ but another had $90 \%$. The breakdown for graduate students was I library with no use, 17 with $25 \%$ and less, 27 with $26 \%$ to $50 \%$, I3 with $51 \%$ to $75 \%$, and 5 with $76 \%$ or more. Faculty use indicated one library with no patrons, 35 with $25 \%$ and less, 18 with from $26 \%$ to $50 \%, 7$ with $51 \%$ to $75 \%$, and 2 with $76 \%$ or more. Of users classified as others, 37 libraries reported none and the percentage for the other libraries ranged from $\mathrm{I}$ to 60 . As more newspapers and magazines are placed on film, there can be little doubt but that the undergraduate use will increase proportionately. Such a trend may have drawbacks on the one hand but it should be a boost to the microfilm program in helping students to become educated sooner than normally to the use of film in libraries.

To have some data directly from the users of microfilm, 20 patron data forms were sent to eighty of the libraries with the request that the forms be completed. Most libraries were reluctant to ask their clientele for cooperation, and so only 496 completed forms were returned to the subcommittee. From the answers, we learned the frequency of microfilm use by nearly 500 patrons during the regular school year or nine months was as follows:

$\begin{array}{rl}71 & \text { I time } \\ \text { IO6 } & 2-5 \text { times } \\ 87 & 6 \text { - IO times } \\ 55 & \text { I I-20 times } \\ \text { I } 76 & \text { more than } 20 \text { times }\end{array}$

The length of time the machines were used was: 28 for 15 minutes or less, 6 I for 15 to 30 minutes, 103 from 30 to 60 minutes, 173 from I to 2 hours, and I3I for more than 2 hours. Of the types of material used on microfilm, newspapers led with 239 , books were used ror times, magazines 52 times, and other than these but generally manuscripts I 84 times. In some instances, more than one type of material was checked. In regard to the reaction to the use of microfilm, 285 patrons indicated that although the printed or codex book was preferred there was no objection to microfilm, 89 expressed a preference for microfilm, 72 stated no preference, $47 \mathrm{ob}-$ jected to using film, and 3 supplied no answer. As to be expected, the most common objection to microfilm was that it caused eyestrain, but 
other factors with a high number of checks were "cumbersome to use," "inconvenience in scheduling the reading machine," and "headaches." More than half, 282 to be exact, of the patrons reported microfilm can be read as rapidly as a codex book. The final item requested classification of the user as to undergraduate, graduate student, faculty member, or other, and of the 496 replying the division was $77,219,142$, and 53 respectively. These figures on the users of microfilm do not compare unfavorably with those reported above as the average for the 63 libraries furnishing user data, although arrived at quite differently.

Summary: From data submitted by 76 college and university libraries, certain findings on microfilm in this type of library are now evident. The libraries in most states of the nation are represented, and although the greatest number of them are the largest libraries, included too are those of some of the youngest institutions. Not too numerous are the smaller libraries, those whose holdings of books number less than 200,000 volumes and whose student clientele is below the 5,000 mark.

The combined microfilm holdings of the libraries number 164,57 I reels. Deducting 21,047 reels not divided into type of publication on film, we find that of the remaining newspapers constitute nearly $69 \%$ of the total, books $12 \%$, manuscripts $7 \%$, periodicals slightly less than $7 \%$, documents $5 \%$, and separates $1 \%$. The number of reels in the microfilm collections of the libraries ranges from 3 to 20,000 reels. Thirty-three libraries own less than I,Ooo reels each, 20 have from I,000-I,999, and 23 report 2,000 or more.

The number of reels of newspapers most common to libraries is fewer than 600,35 libraries reporting in that range, but of periodicals it is fewer than 100 reels.

With but a few exceptions, the libraries have ceased to bind newspapers which are to be retained indefinitely, but instead are using microfilm for preservation and storage. The reasons for this change are obvious and need no explanation. Sixty-six of 74 libraries report current newspapers on film where they are to be kept permanently. Periodicals, however, proportionately are being changed rather slowly to film and mainly in the smaller libraries, and yet microfilming seems to offer the best solution to the costly problem of storage.
University Microfilms advises that of 107 college libraries subscribing to from I to 125 current periodicals on film, 52 of the libraries receive 20 or more titles. This number of subscribing libraries is much higher than the 18 reported to the subcommittee, and of the 18 only 6 receive 20 or more film subscriptions. Apparently, this difference is due to so few small libraries having been included in the survey. Considering that II6 public libraries also subscribe to periodicals on film and that commercially film subscriptions have been available but a few years, there seems to be little doubt but that librarians are considering the utilization of film in preference to binding more rapidly for magazines than they did for newspapers. Of course, if the change is to be made, the sooner the better, but in most of the libraries, there is still a strong inclination to follow the policy of waiting and watching. There is, to be sure, much interest evidenced in the change and only $20 \%$ have rejected the idea completely.

With college and university libraries the policy has been to select titles on film which will be little used, mainly scientific, technical, and professional journals, and so far the majority of the libraries seems satisfied. Certain objections have, of course, been made, notably the absence of color from pictures and the blackness of pictures in film, and there are still "bugs" to be worked out in the filming of the magazines by the processors, but on the whole the reports are encouraging.

The two main factors in placing magazines on film rather than binding them are the saving in space and the difference in the cost of the film and of the binding costs. Other important factors are the use to which the material is to be put, and the availability of a needed item.

No figures are available for comparing the current patron reaction to microfilm with that of ten years ago, but gradually microfilm is becoming better accepted, and as more undergraduates use film, the opposition to it will be lessened considerably. The percentage average for 63 libraries showed microfilm users to be 22.08 undergraduates, 43.27 graduate students, 30.95 faculty, and 3.74 others. Of 496 users of microfilm 285 indicated a preference for the codex book but had no objection to film, 89 expressed a preference for film, 72 stated no preference, 3 supplied no answer and 47 definitely objected to using it.

There is a strong feeling on the part of 


\section{Table I}

\section{Reels of Microfilm Resources by Types of Publications}

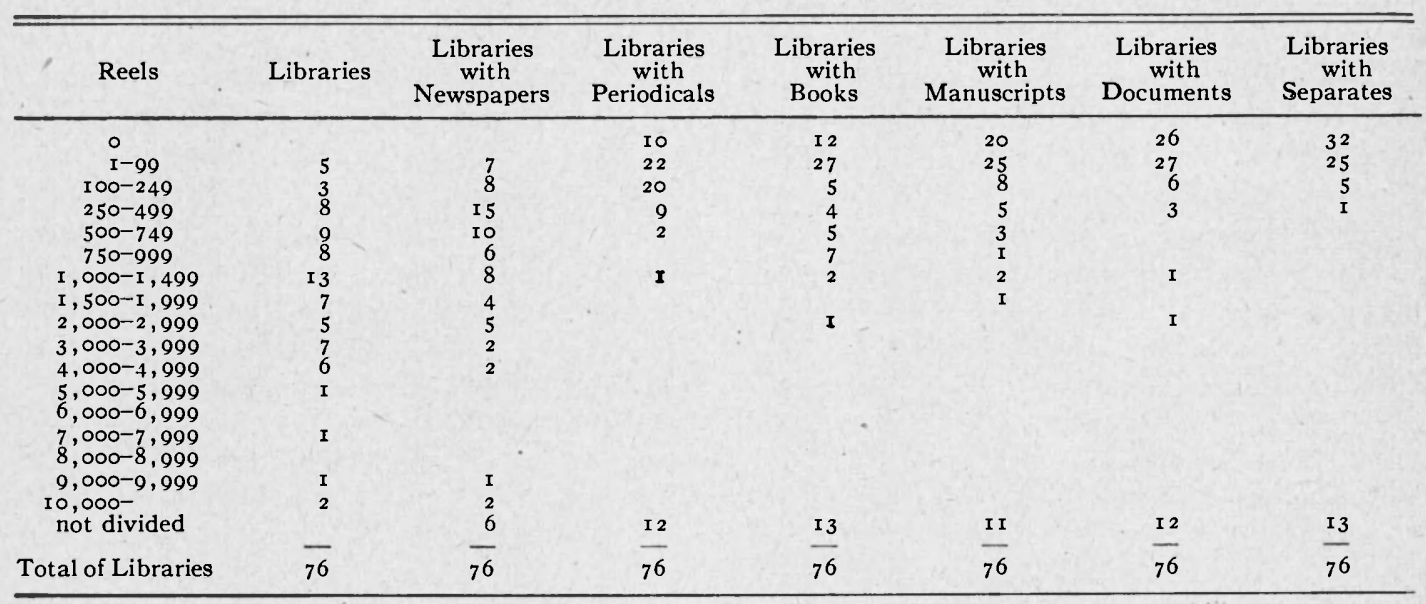

\section{Table II}

\section{Institutions with 1000 or More Reels of Microfilm}

\begin{tabular}{|c|c|c|c|c|c|c|c|c|}
\hline Institution & $\begin{array}{l}\text { Total } \\
\text { Reels }\end{array}$ & $\begin{array}{l}\text { Reels of } \\
\text { News- } \\
\text { papers }\end{array}$ & $\begin{array}{l}\text { Reels of } \\
\text { Periodi- } \\
\text { cals }\end{array}$ & $\begin{array}{c}\text { Reels of } \\
\text { Books }\end{array}$ & $\begin{array}{l}\text { Reels of } \\
\text { Manu- } \\
\text { scripts }\end{array}$ & $\begin{array}{l}\text { Reels of } \\
\text { Docu- } \\
\text { ments }\end{array}$ & $\begin{array}{l}\text { Reels of } \\
\text { Sepa- } \\
\text { rates }\end{array}$ & $\begin{array}{l}\text { Reels } \\
\text { Not } \\
\text { Divided }\end{array}$ \\
\hline Alabama & $1,310 * *$ & & & & & & & I, $310 * *$ \\
\hline $\begin{array}{l}\text { Arkansas } \\
\text { Brown }\end{array}$ & 1,520 & I, 276 & I 82 & 3 I & 8 & 23 & & $3,607 * *$ \\
\hline California (Berkeley) & 4,676 & 605 & & & & & & 4,071 \\
\hline $\begin{array}{l}\text { California } \\
\text { (Los Angeles) }\end{array}$ & I , 838 & 544 & 299 & 493 & $33 I$ & 28 & 2 I 3 & \\
\hline Chicago & 20,000 & I 5,000 & & & 30 & & $2+3$ & 5,000 \\
\hline $\begin{array}{l}\text { Colorado } \\
\text { Columbia }\end{array}$ & I, 077 & & & & 12 & & & $\mathbf{I}, 077$ \\
\hline $\begin{array}{l}\text { Columbia } \\
\text { Duke }\end{array}$ & $\begin{array}{l}5, \text { I } 41 \\
4, \text { I } 18\end{array}$ & $\begin{array}{l}2,815 \\
2,783\end{array}$ & $\begin{array}{l}350 \\
250\end{array}$ & $\begin{array}{l}652 \\
850\end{array}$ & $\begin{array}{r}\mathrm{I}, 2 \mathrm{I} 2 \\
\mathrm{I} 85\end{array}$ & $\begin{array}{l}14 \\
50\end{array}$ & 98 & \\
\hline $\begin{array}{l}\text { Florida State Univ. } \\
\text { Florida }\end{array}$ & 4,206 & 4,036 & 7 & 60 & $\begin{array}{r}103 \\
80\end{array}$ & & & \\
\hline $\begin{array}{l}\text { Florida } \\
\text { Harvard }\end{array}$ & $\begin{array}{l}3,465 \\
4,500\end{array}$ & $\begin{array}{l}3,046 \\
3,375\end{array}$ & I I 6 & 208 & 89 & 99 & 7 & I , I 25 \\
\hline Illinois & 3,890 & I, 847 & I 50* & $800 *$ & $950 *$ & I00* & $43^{*}$ & \\
\hline & I, 235 & 908 & I 6 & $2 I$ & I 56 & 108 & 26 & \\
\hline Johns Hopkins & 2,800 & $\mathrm{I}, 582$ & $\begin{array}{l}\text { I I } 4 \\
238\end{array}$ & 889 & & 215 & & \\
\hline Kansas & $\mathrm{I}, \mathrm{I} 62$ & $\begin{array}{l}431 \\
793\end{array}$ & $\begin{array}{l}238 \\
209\end{array}$ & $\begin{array}{l}\text { I } 55 \\
\text { I } 31\end{array}$ & $\begin{array}{r}30 \\
4\end{array}$ & & 25 & \\
\hline Kentucky & 2,455 & I, 045 & 376 & 651 & $383^{4}$ & & 7 & \\
\hline Louisiana State & 3, I 38 & 2,418 & 210 & & 505 & & 5 & \\
\hline Michigan & 4,671 & 450 & 550 & $2,96 \mathrm{I}$ & 500 & 200 & & \\
\hline Minnesota & 7,832 & $4,97 \mathrm{I}$ & 403 & I , I 27 & 99 & I , I 88 & 44 & \\
\hline $\begin{array}{l}\text { Missouri } \\
\text { New Mexico }\end{array}$ & $\begin{array}{l}\text { I } 5,000 \\
\text { I, I00* }\end{array}$ & $\begin{array}{r}\text { II }, 500^{*} \\
370^{*}\end{array}$ & I, 200 & $I, \infty 00$ & $I, 000$ & 300 & & $730 *$ \\
\hline North Carolina & 3,260 & 528 & & & 334 & 2,263 & & I 35 \\
\hline $\begin{array}{l}\text { Ohio State } \\
\text { Pennsylvania }\end{array}$ & $\begin{array}{l}1,000^{*} \\
4,000\end{array}$ & 2,738 & 185 & 879 & I 98 & & & $\mathrm{I}, \infty 00^{*}$ \\
\hline Pittsburgh & $\begin{array}{l}4,800 \\
3,804\end{array}$ & 2,908 & 267 & 506 & 35 & & 76 & \\
\hline Princeton & 2,596 & $\mathrm{I}, 308$ & 425 & 157 & 301 & $33^{8}$ & 67 & \\
\hline Rochester & 1,076 & 608 & 76 & $3 I I$ & $8 I$ & & & \\
\hline Rutgers & $I, 37 I$ & $I, I 8 I$ & 66 & 20 & IO4 & & 4 & \\
\hline South Carolina & $I, 350$ & $I, 228$ & I & 3 & 59 & 59 & & \\
\hline Southern Calif. & 1,038 & 440 & $9 \overline{8}$ & I 7 & 97 & 97 & I $78 \dagger$ & \\
\hline Stanford & $\mathrm{I}, 073$ & 703 & 23 & 78 & 236 & 33 & & \\
\hline Temple & $\mathrm{I}, 855$ & $I$, OI 8 & 242 & $565^{*}$ & 30 & & & \\
\hline Tennessee & I, 555 & 889 & 400 & 28 & 89 & I 4.5 & 4 & 583 \\
\hline $\begin{array}{l}\text { 1exas } \\
\text { Utah }\end{array}$ & $\begin{array}{l}3,154 \\
2,052\end{array}$ & I, 637 & 4 I 5 & & $\mathrm{I}, 57 \mathrm{I}$ & & & 1,503 \\
\hline Virginia & $\mathrm{I}, 779$ & 295 & $92 *$ & 797 & 568 & $9^{*}$ & I $8 *$ & \\
\hline Washington (St. Louis) & I, 693 & I, 617 & & & 39 & 3 & 34 & \\
\hline Washington (Seattle) & $I, 440$ & 367 & 533 & & & & & 540 \\
\hline Wayne & 1,000 & 90 & I 50 & 800 & & 100 & & \\
\hline $\begin{array}{l}\text { Univ. of Wisconsin } \\
\text { Yale }\end{array}$ & $\begin{array}{l}9,500 * * \\
2,600 *\end{array}$ & $\begin{array}{l}9,000 * * \\
\mathrm{I}, 100 *\end{array}$ & $370^{*}$ & $750 *$ & $370 *$ & & & 500 \\
\hline
\end{tabular}

+ Indicates music scores.

* Figure estimated.

**A Alabama reported I,3 ro cataloged items, Brown 3.60 7 pieces and rolls, and Wisconsin includes State Historical Society 
the subcommittee that much of the objection to microfilm is psychological. No tests have been made to learn how valid the objections expressed most often really are. No doubt, a contributing cause to the aversion for film is that the microfilm facilities are substandard. Only 3 of 75 libraries indicated their facilities were excellent and in each of these there was a high percentage of satisfied patrons. Certainly, there is great need for educating to film use not only the public but also librarians, many of the latter being apathetic and even daunted because some slight mechanical sense is required.

Just how far libraries will go in using film in preference to binding, no one can say for sure. The time must pass to permit a thorough comparison of the different types of micro-reproduction. No doubt, the five year experiments being conducted with microfilm by several college libraries will go far in providing necessary information for a decision. Possibly, by 1960 many librarians will have taken a definite stand, but of course, many others will still be waiting and watching. However, until there is developed a form of reproduction which will suit the library clientele better, and yet offer as many advantages as microfilm, at least for much of the periodical literature, there seems no better solution to the problem of costly storage.

\section{American Historical Association}

\section{(Continued from page 306)}

sults of the various microcopying projects. It is the desire of the committee to promote the principle of a centralized depository in the Library of Congress in connection with an inexpensive interlibrary loan service. This principle the Librarian of Congress has indorsed.

But interlibrary loan service to be effective must be supplemented by a publication of the micro-acquisitions, both old and new, of the Library of Congress so that scholars will know what is available. The committee is endeavoring to publicize the results of its programs by printing the checklists of materials obtained and deposited in the Library of Congress in the Annual Report of the American Historical Association, Vol. I. Proceedings as supplements to the annual committee reports. ${ }^{4} \mathrm{We}$

4 For checklists submitted by research scholars jointly sponsored by the Committee on Documentary Reproduction and the Library of Congress see "Committee on Documentary Reproduction," Annual Report of the American Historical Association for the Year I951; 1952, erican Historical Association for the Year
Vol. I, Proceedings (publication pending) are encou raging our jointly sponsored research scholars to submit for publication in the American Archivist articles related to their work in foreign archives that will be helpful to colleagues who may follow them in work abroad. ${ }^{5}$ Attention should also be called to the Library of Congress Quarterly Journal of Current Acquisitions for information regarding the microfilm holdings of the Library of Congress. I wish in particular to cite an article in the November, 1952 issue of the Quarterly Journal by Dr. Lester K. Born, entitled "Microreproductions" for an excellent summary of the Library of Congress holdings in micro-materials, as a good start for learning of the vast resources that already have been acquired by the library and that are available to the scholar.

\footnotetext{
- For articles already published see Rice, Howard $\mathrm{C}_{\text {; }}$ Jr., "The Paris Depository for Notarial Archives," American Archivist, 14:99-104, April, 195I ; Topping, Peter. "The Public Archives of Greece," American Archivist, I 5 :249-257, July, 1952.
}

\section{Suggestions for ACRL Publications Committee}

One of the functions of the ACRL Publications Committee is to recommend needed booklength studies in the college and university field to the ALA Publishing Department. There are, undoubtedly, many good ideas for books in the minds of ACRL members, and, in order to get them discussed and presented to the ALA Publishing, such requests should be channeled to the ACRL Publications Committee. ACRL members who have suggestions are requested to send them to Lawrence S. Thompson, chairman, ACRL Publications Committee, University of Kentucky Libraries, Lexington, Kentucky. 